certain views put forward by me in your columns in March, 1869 , to much the same effect as those I now advocate. I am, Sir, jour obedient servant.

Oxford, Dec. 19th, $19 \%$. George Rolleston.

\section{RESECTION OF JOINTS IN MILITARY PRACTICE.}

To the Editor of THE LANCET.

Srn,- Your report of the proceedings of the last meeting of the Pathological Society would convey to your readers a rather sreeping condemnation on my part of all attempts at conservative surgery, more especially resections, in military practice.

It is, I think, certainly true that, in severe gunshot fractures of the lower limb, amputation is often the better course, and that, when not performed in the first instance, it often becomes imperative at some later neriod in order to afford a chance of life, and then the conditions for success are not at all so favourable. It is also true that resections of the hip, and especially of the knee, have not been satisfactory.

In the upper extremity, however, the converse holds true, and resections of the shoulder, the elbow, and the wrist, as a rule, do well; while, compared to the leg and thigh, amputation of the forearm and arm is but rarely needed.

It cannot be too strongly insisted upon, that where an operation is required from the severity of the injury, an immensely better chance of success is afforded by perlorming the operation at once, and it therefore becomes of great importance to make an early and thorough examination of all gunshot wounds by the finger. No probe, however cunningly devised, will answer so well.

In your special correspondent's valuable communication on "' The Surgery of the War," I may make a correction, of which he doubtless will be glad to hear. In the interesting and, I believe, unique case where I excised the shoulder and elbow joints in the same arm, the patient did not die. In fact, I only yesterday bad the pleasure of receiving a letter dictated by him under date of December $4 \mathrm{th}$, in which he expresses his mreat gratitude for what has been done for him, and his expectation of a speedy recovery. Your correspondent is in error in attributing to Stromeyer the performance of thirty-six resections of the knee-joint. It is an operation which, as applied to military surgery, that distinguished authority emphatically condemns. I have only to add that I agree most perfectly with the pertinent remarks of Mrr. Hulke, "that every campaign must be treated upon its own merits, and that it would not be right to repudiate conservative surgery in military practice altogether."

I am, Sir, your obedient servant,

WILLTAM MACCoRmac.

Grosvenor-street, W., Dec. 17th, 1870.

\section{THE TEAGHING OF PRACTICAL PHYSIOLOGY.} To the Eulitor of THE LANCET.

Sre,-May I beg the favour of a small space in your columns to correct an impression which may possibly have been made on the minds of your readers by an allusion, in the last week's number of jour journal, to some remarks of mine on the teaching of Practical Physiology in the schools.

I certainly made an objection to such teaching, in accordance with what I believe to be a widespread feeling amongst the teachers in the metropolis; but not solely or chiefly, as allegred, on the ground that it would be likely to revive and encourage the practice of vivisection. I admit this to be a very cogent objection, but I dissent still more strongly for another reason, which had not, in your remarks, a corresponding prominence given to it. I object because I cannot help thinking that the time given by students to Practical Physiology might be more advantageously employed in the acquirement of the more rudimental and important parts of a professional education. If by a reference to the several Courts of Examiners it could be satisfactorily shown that, as a rule, the students, on presenting themselves at the "pass" examinations, are thoroughly well up in, more especially, anatomy, regional and histological ; in physiology, as learnt by inference and by the usual instructions of their teachers; and in practical medicine aud surgerywell up, in short, in those branches which would yield an adequate stock of knowledge for all the resources of a competent practitioner of his profession, and be a basis for higher attainments, then, by all means, under certain restrictions, let physiology be taught practically as well.

But I have reasons for thinking that such an appeal would not be satisfactorily responded to; but that, on the other hand, it is too frequently felt at these boards that the knowledge, even in these branches, is lamentably defective. If such really be the case, is it likely that the student who is puzzled to describe the ethmoid or sphenoid bone, or the fifth pair of nerves, or to answer very much more simple questions in anatomy, and the simplest in surgery, would be capable of appreciating or understanding experiments on the ragus, or on the orey matter of the cord, or would be in the least degree enlightened on the subject of systole or diastole by the exhibition of an unencased living heart? I cannot think that he would.

Our educational course is not designed to make men great, so much as competent members of their profession. The former will always make themselves.

The faults indicated in these remarks do not, in $\mathrm{my}$ opinion, rest so much with the students as with the course of instruction to which they are compelled to submit themselves. According to the existing curriculum, their time and brains are overweighted. They are required to learn, within a given period, more than they can possibly understand. And I humbly submit that, if any alteration should be made in the course of study, it should be in the direction of less learning but betier learnt.

I am, Sir, your obedient servant,

Finsbury-place South, December 21st, 1870.

JOHN GAY.

\section{SANITARY SCIENOE AFLOAT.}

To the Editor of THE LANCET.

SrR,-In your annotation on this subject in your issue of the 10 th December you say you will be glad to know the experience of the medical officers of the Flying Squadron, during their late voyage round the world, as to the use of preserved meats. I hope many of them will comply with your request, as this is really a professional subject, and cannot surely come within the scope of the Admiralty order as to officers of the fleet writing in public journals. If they are silent you must put it down to this order rather than to want of zeal.

When I was surgeon of H.M.S. Nimrod several years ago, preserved meat and vegetables were used both by officers and men on the voyage to China, and with the best effects, as the crew arrived on the station in excellent health and spirits. The various sanitary suggestions which I made were most kindly and promptly carried out by my late lamented friend, Captain Roderick Dew, R.N., and with such good results that I am thankful to say not a single death occurred for a whole year, as will be found by my journal, lodged in the office of the Medical DirectorGeneral of the Navy. I have, in former letters in your columns, repeatedly urged the great importance of the issue of preserved meat and vegetables both in the Royal Nary and the mercantile marine. The excellence and comparative cheapness of the supply from Australia will doubtless give a stimulus to the increased consumption of preserved meat both ashore and afloat. A good supply of fresh water on board ship is most important, and this can now be obtained in all steam vessels by a well-known process. As the Admiralty complimented Adniral Hornb $\bar{y}$ on the economy of fuel on board his ships, you may be sure neither officers nor men were overwhelmed with the liberality of their water-supply.

I am strongly of opinion that in this squadron there should have been a deputy inspector-general, specially qualified to record and utilise his experience in naval hygiene, \&c.; but the bugbear of economy-or rather unwise and injudicious parsimony-prevails in the councils of the Admiralty (while lavish in their expenditure on ex- 